\title{
Performance of Broiler Chickens Fed on Cassave Peels and Rice Bran As Energy Substitute to Maize
}

\author{
Ghomsi MO ${ }^{1}$, Doube TB ${ }^{1}$, Etchu $\mathrm{KA}^{1 *}$, Fotso $\mathrm{JM}^{2}$, Tchakounte $\mathrm{J}^{2}$, Mongo $\mathrm{GB}^{1}$ and Ahoumo $\mathrm{L}^{2}$ \\ ${ }^{1}$ Institute of Agricultural Research for Development (IRAD), Yaoundé, Cameroon \\ ${ }^{2}$ The Research Debt Relief Support Program - C2D/PAR/IRAD Projet Volailles
}

Received: 25 August, 2017; Accepted: 04 October, 2017; Published: 10 October, 2017

*Corresponding author: Etchu Kingsley, Institute of Agricultural Research for Development (IRAD), Yaoundé, Cameroon,

E-mail : etchu74@gmail.com

\begin{abstract}
Conventional livestock production like poultry, pigs, cattle and goats have maintained a steady dominance over the non-conventional species like snails and grass cutter. Despite this dominance, conventional livestock production is dependent on their nutrition which constitutes about $60-65 \%$ of the total production cost. With the current trend of the Cameroon economy where the available feed ingredients especially maize are being over used by humans for their feeding, it becomes imperative that alternative feed ingredients be sorted for sustainable production. Cassava production so far has dominated the root and tuber sector in Cameroon. The varieties introduced by IRAD and grown in all the five agro-ecological zones produce 30-40 tons per hectar. Like cassava, the Nerica variety of rice introduced is equally accepted and grown in all the agro - ecological zones of Cameroon and beyond producing to the tune of $5-7$ tons for irrigated low land variety and $3-4$ tons for the upland variety. Rice like cassava processing produces large quantities of waste and is generally considered to contribute significantly to environmental pollution. This study was carried out to intensify the use of rice bran and cassava peels for efficient and sustainable broiler production. Rice Bran and Dried Cassava Peels were collected from Ndop and Mbalmayo respectively and were futher dried to minimum moisture less than $4 \%$ and analyzed for their proximate nutritive content. The dried rice bran and cassava peels were used to formulate the rations and fed to a total of 258 chickens of arbor acre aged 30 days and weighing an average of $639 \mathrm{~g}$. In a complete randomized design, the birds were distributed in 3 treatments of 86 chickens and each with 03 replicates of 29 birds. Animals fed $\mathrm{T}_{2}$ diets consumed more feed than those fed on $\mathrm{T}_{0}$ and $\mathrm{T}_{1}$. Meanwhile, the final weight of chickens fed on the control diet was higher than the birds fed on $T_{1}$ and $T_{2}$ while the consumption index was higher in animals fed $\mathrm{T}_{1}$ and $\mathrm{T}_{2}$. At the end of this study, it was found that: The dried cassava peels and rice bran can substitute maize as energy source for sustainable broiler production. Their energy levels are comparable to that of maize. However, higher levels above $15 \%$ except fermented, would lead to a decrease in the performance of Broiler birds.
\end{abstract}

Keywords: Dried Cassa va Peels; Rice Bran; Agro Industrial By Products; Broiler Chicken ;

\section{Introduction}

Processing of cassava produces large quantities of waste and is generally considered to contribute significantly to environmental pollution [12]. Cassava starch production unit processing 100 tons of tubers per day has a production of 47 tons of fresh byproducts, which can cause environmental problems when left in the vicinity of plant treatment or negligently disposed of [2]. In Nigeria, for example, cassava waste is generally left to rot or burned to create space for the accumulation of even more heaps. The clusters emit carbon dioxide and produce a strong offensive odor $[1,2]$. Cassava peels (large quantities of cyanogenic glucosides) and corks (large amounts of biodegradable organic matter) can cause surface water pollution, especially if stored in the rain or simply thrown into surface waters $[7,4]$. The variability of rice bran, and in particular its fiber content, has a very high effect on its nutritional value for poultry [6]. High-lysine rice bran and the content of methionine [13]. Cameroon, like many African countries, is experiencing significant population growth. Ensuring food security depends on intensifying livestock production in general and poultry production in particular. However, this sector faces several constraints, as is the high cost of the ingredients used in the rations. These ingredients account for approximately $60-70 \%$ of the cost of poultry production.

Hence the study of the effect of cassava peels and rice bran on the growth performance of finely brown chickens.

\section{Literature Review}

\section{Analytical methods}

Cassava peels can be used for feeding poultry after sun drying, so processed peels contain HCN levels that are acceptable for poultry $[17,18]$. The method of fermentation of cassava peels has been tested by several authors, whether to lower HCN or fiber content or to increase the crude protein content, but the results do not Are in conclusive [5]. 
In some experiments, growth performance was maintained with flesh diets containing up to $15 \%$ meal cassava peels [18]. Food intake is generally not very affected, but depends on the formulation of foods (isoenergetic diets or not). However, in some performance experiments decreased by $5 \%$ of peel manioc flour in diets [9]. This may be due in part to problems in food formulation as it is proven that performance degrades with insufficient inclusion of proteins [9]. There may be an advantage in feeding fresh cassava peels to slow-growing chickens [19]. The recommendation of broiler chickens is to limit the incorporation of cassava meal peels to 5-10 \% depending on its quality, with a suitable feed formulation. Higher levels of cassava meal peels might be required to slow down the growing chicken, or in situations where depression in growth performance is counterbalanced by a lower feed cost.

\section{Rice bran}

In broiler chickens, rice bran can become rancid and reduce the growth and stability of meat lipids (Chae et al., 2002). It is suggested that it be included at relatively low levels (up to $15 \%$ only) in broiler chickens diets [14]. Higher levels may result in poor calcification [3]. Decreased food consumption and increased mortality can occur with more than $80 \%$ inclusion [6]. In order to mitigate the adverse effects of phytate, enzyme inhibitor and oxidative rancidity as well as high fiber content, enzymes such as phytase, xylanase or lipase can be added to the rice bran, allowing $\mathrm{T}_{\mathrm{o}}$ include higher levels of rice bran in the broiler chicken diet and resulting in better performance of the animal. Technological treatments can alter the nutritional value of rice bran for broiler chickens. Heating decreased nutritional value, but cooking by extrusion of rice makes its possible inclusion at 20 $\%$. Combinations of rice bran with other fillers may be beneficial for broiler chickens: $10 \%$ rice bran $+5 \%$ palm oil yielded results comparable to those of commercial concentrates [16]. Rice bran and meal peanut blends gave higher gross margins than corn soy meal diets. Rumen liqueur can also be added to the rice bran to solubilize $\mathrm{P}$ content in phytates, which makes $\mathrm{P}$ supplementassions decreased possible. Although rice bran does not compare favorable with maize, it can replace up to $25 \%$ of maize in food and be economically efficient $[11,15]$.

\section{Problem}

In poultry farming, the cost of food accounts for about $70 \%$ of the cost of production.

Lower production costs would mean finding new sources of low-cost, abundant, local and available food.

\section{Hypothesis}

The use of cassava barks and rice bran as an alternative source of energy would improve the growth performance of finely brownchickens

\section{activity has the under listed as general and specific objectives.}

\section{General objective:}

1. Intensify the use of rice bran and cassava peels for efficient and sustainable broiler production.

\section{Specific objective}

1. To increase the use of agro-industrial by-products (rice bran and cassava peels) for good quality broiler production.

2. Reduce environmental pollution through careless dumping of the rice bran and cassava peels following rice and cassava processing.

3. To improve on the income of the rural farmer and strengthen the capacity of poultry farmers.

\section{Material And Methods \\ Collection of the feed samples (ingredients) :}

Rice Bran and Dried Cassava Peels were collected from Ndop and Mbalmayo respectively. The rice bran is a major by-product of the rice factory managed by UNDVA program. It produces over 15.000 tons of rice bran per anum. The Dried cassava peels were collected from an Innovation Platform group whose one activity is cassava processing. The rice bran and dried cassava peels were futher dried to minimum moisture less than $4 \%$ and analysed for their proximate nutritive content.

\section{Study Site}

The study was carried out at the experimental farm of the Agricultural Research Institute for Development (IRAD) in Nkolbisson, in the western suburbs of Yaoundé, a forest region in central Cameroon. This center is located at $3^{0} 86$ of Longitude North and $11^{0} 5$ of Latitude East. This agro-ecological zone is characterized by an average temperature varying between 23 and $25{ }^{\circ} \mathrm{C}$, a bimodal rainfall of 1500 to $2500 \mathrm{~mm}$ / year and a relative humidity ranging between 70 and $90 \%$. The climate is of the subequatorial type marked by four seasons ( 2 dry seasons and 2 seasons of rain) [10].

\section{Animals, experimental rations and experimental design}

A total of 258 chickens of arbor acre stature aged 30 days and weighing an average of $639 \mathrm{~g}$ were distributed in 3 treatments of 28 chickens each. The chickens were housed in groups of 3 in boxes, which made 3 experimental units per treatment. They were reared on deep litter at a density of 10 chickens / $\mathrm{m} 2$. Each of the experimental rations $\mathrm{T}_{0}$ (free from rice bran and cassava bark), $\mathrm{T}_{1}$ (containing $5 \%$ rice bran) and $\mathrm{T}_{2}$ (containing $4 \%$ cassava bark) were assigned to these experimental units completely randomized (Table 1,2 ). The test was completed when the chickens were 46 days old. Food and water were served ad libitum. 
1. Proximate analysis of the feed ingredients

Table 1: Proximate composition of Dried cassava peel and Rice bran (\% dry weight)

\begin{tabular}{|c|c|c|c|c|c|c|}
\hline Sample & Ash & Moisture & Protein & Fat & Crude Fibre & Carbohydrate \\
\hline Cassava peels & $9.82 \mathrm{~b} \pm 0.4$ & $90.01 \mathrm{c} \pm 0.3$ & $18.49 \mathrm{c} \pm 0.1$ & $3.43 \mathrm{a} \pm 0.4$ & $6.5 \mathrm{a} \pm 0.2$ & 3160.3 \\
\hline Rice bran & $7.76 \pm 04$ & $90.33 \pm 02$ & $18.95 \pm 03$ & $4.42 \pm 02$ & $6.84 \pm 04$ & 3268.1 \\
\hline
\end{tabular}

Values with the same alphabet along the same column are not significantly different $(\mathrm{P}>0.05)$.

Values are mean \pm S.E $(n=3)$.

2. Formulation of rations

Table 2: Formulated Rations for the study using rice bran and dried cassava peels as energy substitute for maize

\begin{tabular}{|c|c|c|c|}
\hline \multicolumn{4}{|c|}{ Feed formulation for the trial } \\
\hline Ingredient/ Level of inclusion & $\mathrm{T}_{\mathrm{o}}$ & $\mathrm{T}_{1}-\mathrm{PRB}$ & $\mathrm{T}_{2}-\mathrm{PDCP}$ \\
\hline Maïs & 55.68 & 51,68 & 52,68 \\
\hline Rice Bran (9\% Maize) & 0 & 5 & 0 \\
\hline Dried Cassava peels (7.2\% Maize) & 0 & 0 & 4 \\
\hline Tourteau de soja & 22 & 23 & 23 \\
\hline Tourteaud'arachide & 7 & 7 & 7 \\
\hline Farine de poisson & 5 & 5 & 5 \\
\hline Coquillage & 2 & 2 & 2 \\
\hline Os & 1 & 1 & 1 \\
\hline Méthionine & 0,15 & 0,15 & 0,15 \\
\hline Lysine & 0,15 & 0,15 & 0,15 \\
\hline CMAV $5 \% 1$ & 5 & 5 & 5 \\
\hline Sulfate de fer & 0,02 & 0,02 & 0,02 \\
\hline TOTALS & 98 & 100 & 100 \\
\hline CP - \% & 21.45 & 21.82 & 21.84 \\
\hline Energy - K.Cal/g & 2834 & 2808 & 2772 \\
\hline Number of birds/ Replicates & $60(20 \times 3)$ & $60(20 \times 3)$ & $60(20 \times 3)$ \\
\hline
\end{tabular}

\section{Data collection on the performance of the performance of the animals}

Data was collected on performance indicators such as feed intake, growth rate, from which feed efficiency and feed conversion ratrion will be collected ; mortality and cost efficiency (Figure 1).

\section{Data collection and analysis}

\section{Feed consumption}

The previously weighed feed was distributed to the birds and at the end of each week, the remains were weighed. Weekly food consumption was assessed by distinguishing between the quantities served and the rejections collected in each experimental unit.

\section{Live weight and weight gain}

At the beginning of the test and every 7 days thereafter, the chicks from each experimental unit were weighed. The weekly weight gain was obtained by making the difference between 2 consecutive weekly weights.

\section{Consumption index (I.C.)}

The consumption index was obtained by comparing the amount of food consumed and the weight gain during the same week:

$$
\text { I.C. }=\frac{\text { Amount of feed consumed per animal }(\mathrm{g})}{\text { Average weekly gain. }(\mathrm{G}) .}
$$

\section{Results and discussion}

\section{Food consumption:}

In general, food consumption has been affected significantly by the different treatments, but it appears to be higher in $T_{2}$. Animals fed $\mathrm{T}_{2}$ food consumed more food than those subjected to $\mathrm{T}_{0}$ and $\mathrm{T}_{1}$ treatment. This high consumption could be due to the fact that the $4 \%$ level of skin incorporation was far from the incorporation limits obtained by Which was $15 \%$. More interesting results have been obtained with the feeding of fresh cassava peels to slow-growing chickens [19] (Table 3). 


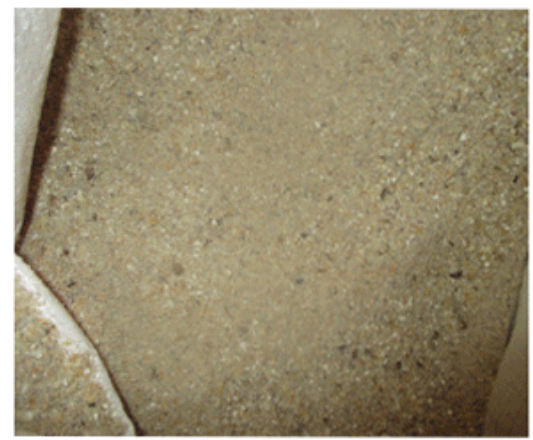

Dried Cassava Peels energy based Ration

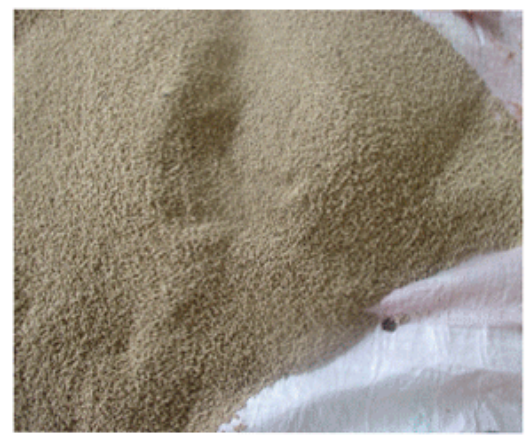

Rice Bran based energy Ration

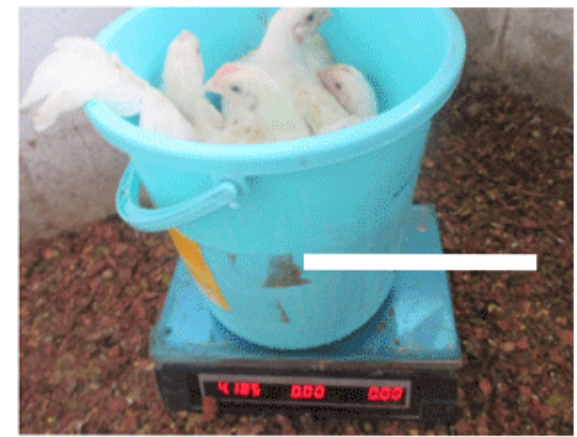

Weighing of the animals

Figure 1:

Table 3 : Effect of Cassava peels and Rice bran on growth parameters

\begin{tabular}{|c|c|c|c|}
\hline \multirow{2}{*}{ Growth Parameters } & \multicolumn{3}{|c|}{ Treatments } \\
\hline Average feed consumption (g) & $\mathrm{T}_{0}$ & $\mathrm{~T}_{1}$ & 3801 \\
\hline Initial average live weight (g) & 3768 & 3714 & 668 \\
\hline Final average weight (g) & 604 & 645 & 1795 \\
\hline Weight gain (g) & 2082 & 1701 & 1105 \\
\hline Consumption Indix & 1472 & 3,55 & 3,50 \\
\hline
\end{tabular}

\section{Live weight:}

The final weight of chickens fed by the control treatment was higher than the birds fed on $\mathrm{T}_{1}$ and $\mathrm{T}_{2}$ test treatments. This would mean that cassava peels and rice bran would lead to a decrease in weight gain during growth with respect to the control.

Weight gain: weight gain is higher $(\mathrm{P}>0.05)$ for animals that consumed the food $\mathrm{T}_{0}$ control

\section{Consumption Index (CI)}

CI is higher in animals fed $\mathrm{T}_{1}$ and $\mathrm{T}_{2}$. This higher consumption index is due to the high feed consumption of $\mathrm{T}_{1}$ and $\mathrm{T}_{2}$ treatments and the low weight gain of the animals fed with the granulated feed. These results corroborate those of Egbunike et al., 2009 which observed a decrease in growth performance has for a diet $5 \%$ rate of incorporation of manioc peel flour [9]. In broiler chickens, rice bran can become rancid and reduce the growth and stability of meat lipids [8]. However, in contrast to authors such as El-Full et al., 2000, which states that rice bran can replace up to $25 \%$ of maize in the diet and be economically effective in broiler chickens [11].

\section{Recommendation}

Though the cassava peels used were not too friendly on the performance of the animals due to poor processing method. However, for subsequent and effective usage, the cassava peels should come from good and edible variety of cassava, which upon peeling should be washed and dried to minimum moisture (lessthan $4 \%$ ) and included up to $15-25 \%$ in the finisher diet.

\section{Conclusion}

At the end of this study, which evaluated the effect of cassava peels and rice bran on the performance of finished broiler chickens, it was found that: The cassava and rice husk peels can substitute maize as energy source for sustainable broiler production. Their energy levels are comparable to that of maize. However, higher levels above $15 \%$ except fermented, would lead to a decrease in the performance of Broiler growths in the respective finishes.

\section{Acknowlegements}

1. The Minister of Scientific Research and Innovations - MINRESI

2. The French Development Cooperation - AFD

3. Centre International de Recherche Agricole pour le Développement - CIRAD

4. Institute of Agricultural Research for Developement - IRAD

5. The Research Debt Relief Support Program - C2D/PAR

As well as individuals, farmer groups, NGOs and other development institutions. Your respective contributions in terms 
of facilitation, valuable time, enabling environment, support and collaboration gave us the reason to successfully carry out this activity.

\section{References}

1. Adebayo AO. The use of cassava waste to raise goats. Project from 2008 to 4345. World Bank Development Market. 2008.

2. Aro SO, Aletor VA, Tewe 00, Agbede JO. Potential nutritional cassava tuber waste: A study of a starch cassava processing plant in southwest Nigeria case. Livest. Res. Rural Dev. 2010 ;22(11).

3. Aruna Tomar, Singh KS. Femoral bone mineralization in chickens fed rice bran. Indian J. Poult. Sci. 1999;34(3):332-336.

4. Barana AC,Cereda MP. Cassava wastewater (manipueira) treatment with the aid of an anaerobic biodigestor two phases. Ciencia e Tecnologia de Alimentos. 2000;20 (2):183-186.

5. Buitrago JA. The use of cassava in animal feed. Centro Internacional de Agricultura Tropical (CIAT), Cali (Colombia). 1990;446.

6. Carrion JG, Lopez J. The total sound of rice as a substitute for corn in the feeding of broiler chickens. 2. Carcass yield and chemical composition. Rev. Soc. Arms. . Zootec.1989;18(4):327-333.

7. Cereda MP, Takahashi M. Cassava waste: their characterization and use and treatment in Brazil. Cassava flour and starch: progress in research and development.1996:221-232.

8. Chae BJ,Lee KH, Lee SK. The effects of rancid rice feed on the growth performance and quality of chicken meat from broiler chicken. AsianAust. J. Anim. Sci.2002;15(2):266-273.

9. Egbunike GN, Agiang EA, Owosibo AO,Fatufe AA. Effect of protein on the performance and hematology of chickens fed cassava bark. Camber. Zootec. 2009;58:655-662.

10.Ekalle NM, Mongo BG1, Ghomsi MOS, Tientcheu BL, Tchakounte J, Hakoue F, et al. Substitution of Groundnut Cake with Palm Kernel Cake on the Growth Agriculture. 2016;2(1):1-7.
11.El-Full EA, Asker AEN, Ali MMM, Abdel Wahed HM, Omar EM. The use of rice bran in flesh and diet diet with reference to enzyme supplementation. Poult egyptienne. Sci. J. 2000;20(3):517-543.

12.FAO. Strategic Environmental Assessment. An assessment of the impact of cassava production and processing on the environment and biodiversity. Proceedings of the Validation Forum on the Global Cassava Development Strategy. FAO, Rome, 26-28 April 2000. 2001;5.

13.Fialho FB, Lopez J, Bellaver C. Effect of rice and manganese sound levels on performance characteristics and bone in broiler chickens. Rev. Soc. Arms. Zootec. 1993;22 (5): 830-838.

14.Gallinger CI, Suarez DM, Irazusta A. The effects of rice sound inclusion on performance and bone mineralization in broiler chickens. J. Appl. Poult. Res. 2004;13(2):183-190.

15.Gupta JJ, Singh KS. Effect of dietary autoclaving of bran and rice oils on their dietary value in broiler chicken diets. Indian J. Poult. Sci. 1988;23(1):29-34.

16.Ibiyo OVM, Atteh JO. Response of broiler chickens to diets containing graduated levels of rice bran with or without palm oil. Nigerian J. Anim. Prod. 2005;32(1-2):39-45.

17.Kratzer FH, Earl L, Chiaravanont C. Factors influencing the nutritional value of rice bran for chickens. Poult. Sci. 1974;53(5):17951800 .

18.Nwokoro SO, Ekhosuehi. Employment Insurance. Replacement effect of corn with cassava peels in the cockerel feed on performance and carcass characteristics. Too much. Anim. Health Prod. 2005;37(6):495501.

19.0gbonna JV, Dredein AO. Effect of wet feed on the performance of chicks of a cock. Too much. Agric. Trinidad. 2000;77(4):262-264. 